\title{
Experimental Organism Ductal Cell Adenocarcinoma
}

National Cancer Institute

\section{Source}

National Cancer Institute. Experimental Organism Ductal Cell Adenocarcinoma. NCI

Thesaurus. Code C156609.

An experimental organism carcinoma that arises from a ductal structure. 